В.Ф. Курдюк, А.П. Огарок

Військова частина А1906, Київ

\title{
ОСОБЛИВОСТІ ПРОЦЕСУ ВИРОБЛЕННЯ РОЗВІДУВАЛЬНОЇ ОЦІНКИ ПІД ЧАС ПЛАНУВАННЯ ТА ВЕДЕННЯ ОПЕРАЦІЙ У СКЛАДІ ОБ'ЄДНАНОГО УГРУПОВАННЯ ВІЙСЬК (СИЛ) ЗБРОЙНИХ СИЛ УКРАЇНИ
}

У статті викладені концептуальні основи та підходи до вироблення розвідувальної оцінки під час планування та ведення операцій в сучасних умовах у складі об'єднаного угруповання військ (сил) Збройних Сил України та інших складових сил оборони, зокрема спільно з краӥнами-членами НАТО. Розглянуто процес вироблення розвідувальної оцінки оперативної обстановки та загальні принщипи ведення розвідки у процесі об’єднаної розвідувальної оцінки оперативної обстановки.

Ключові слова: доктринальний документ, об'єднане угрупованням військ (сил), об'єднана розвідка, розвідувальне забезпечення, об'єднана розвідувальна очінка.

\section{Вступ}

Постановка проблеми. Відповідно до Державної програми розвитку Збройних Сил України на період до 2020 року та Тимчасової інструкції з організації робіт у Міністерстві оборони України та Збройних Силах України щодо впровадження стандартів НАТО [1-2] у Головному управлінні розвідки Міністерства оборони України продовжується робота 3 розроблення доктринальних документів з розвідувального забезпечення у відповідності з Ієрархією доктринальних документів Збройних Сил України (далі - Ієрархія) [3].

Основою структурної побудови доктринальних документів (за стандартами НАТО для Збройних Сил України) є доктрина JP-01 “Застосування Сил оборони держави” (аналог в НАТО - AJP-01 (Allied Joint Doctrine)). В серії JP-2 зазначеної Ієрархії (Розвідувальне забезпечення в Об'єднаних операціях, в т.ч. за видами розвідки) ключовими керівними документами з розвідувального забезпечення визначено доктрину JP-2.0 “Об’ єднана розвідка” (аналог в HATO - AJP-2 (Allied Joint Doctrine for Intelligence, Counter-intelligence and Security)) у поєднанні 3 доктриною JP-2.1 “Процедури розвідки” (аналог в НАTO - AJP-2.1 (Allied Joint Doctrine For Intelligence Procedures)).

Зміст розроблюваних доктрин має відповідати загальній меті - організації ведення розвідки на тактичному, оперативному і стратегічному рівнях під час планування та ведення операцій ЗС України у взаємодії з іншими складовими Сил оборони, в тому числі спільно з країнами-членами НАТО. Визначені керівні документи включають сукупність фундаментальних принципів, якими керуються війська (сили) у своїх діях з метою виконання поставлених завдань, містять концептуальні засади ефек- тивного виконання заходів розвідувального забезпечення угруповань військ (сил) Збройних Сил України, інших складових сил оборони, визначають штабні процедури та функції розвідки на етапах планування і ведення операції, в тому числі спільно 3 країнами-членами НАТО [4].

Викладені в цих документах загальні підходи до процесу планування та розвідувального забезпечення операції є основою для подальшого розроблення нормативних та керівних документів згідно 3 встановленою Ієрархією (бойових статутів для видів 3С України, тактичних публікацій оперативного рівня 3 питань розвідки та ін.) в умовах ведення розвідки ЗС України Об'єднаним угрупованням військ (сил). Розроблені та затверджені доктрини мають бути базовими (основними) для командувачів (командирів), офіцерів штабів та фахівців розвідки і призначені для застосування в органах військового управління стратегічного та оперативного рівнів.

Розроблення проектів доктрин JP-2.0 та JP-2.1 передбачає використання таких термінів, як "розвідувальна оцінка”, “об’єднана розвідувальна оцінка”, “об’єднана розвідувальна оцінка оперативної обстановки" та опис їх суті і змісту в процесі розвідувального забезпечення при плануванні та веденні операцій Об’єднаним угрупованням військ (сил).

Аналогічна термінологія та встановлений порядок дій у подібних ситуаціях застосовується у керівних документах (стандартах) країн-членів HATO [5-10].

Метою статті є викладення концептуальних основ процесу вироблення об'єднаної розвідувальної оцінки при плануванні та веденні операцій в сучасних умовах у складі об'єднаного угруповання військ (сил) Збройних Сил України, інших складових сил оборони (в тому числі, спільно з країнамичленами НАТО). 


\section{Виклад основного матеріалу}

Під час проведення операцій у складі об'єднаного угруповання військ (сил) Збройним Силам України доведеться комплексно діяти у складній оперативній обстановці, де можливими учасниками і загрозами будуть:

тероризм - як незаконне використання або загроза застосування сили (насильства) стосовно осіб або їх власності, щоб примусити чи залякати уряди або спільноти для досягнення своїх політичних, релігійних та ідеологічних цілей;

ворожі держави - країни, які характеризуються ворожим ставленням до України та країн-партнерів НАTO, ї союзників або балансу міжнародного порядку. У різних ситуаціях ворожість може проявлятися або відкрито (словесна або насильницька агресія чи войовничість), або замасковано і проявлятись у вигляді певних актів за наказами відповідних командирів. У цьому випадку ворожість може стати підставою для здійснення агресії;

нестабільні держави і держави з кризою державної влади - держави, які не можуть адаптуватися до мінливих глобальних ризиків, що супроводжуються істотними спалахами насильства, які надалі можуть поширюватися на сусідні країни. Такі держави, як правило, характеризуються неефективним керівництвом, складним економічним становищем i неефективністю військового управління;

гібридні загрози - коли звичайні і асиметричні загрози поєднуються в часі і просторі. Виниклий конфлікт може залучати декілька транснаціональних, державних, групових та окремих учасників, які можуть діяти, як глобально так і локально. Причинами деяких конфліктів можуть бути одночасно міжобщинні насильства, тероризм, кібератаки, повстання, поширення злочинності і широко розповсюджені заворушення;

розповсюдження зброї - процес, що передбачає розповсюдження балістичних ракет, ядерної зброї, інших видів зброї масового ураження, звичайних видів зброї, технологій їх виготовлення та засобів доставки, що загрожує непередбачуваними наслідками для стабільності. Небезпеку становить також неконтрольоване розповсюдження товарів подвійного призначення, які можуть використовуватися для підтримки програм розробки засобів масового ураження, а також інших товарів, заборонених резолюцією Ради Безпеки ООН. Окрему небезпеку становить ймовірність того, що швидке розповсюдження зброї буде вкрай відчутним у деяких найбільш нестабільних регіонах світу.

3 урахуванням зазначених обставин чітке викладення та формулювання положень розроблюваних доктринальних документів 3 розвідувального забезпечення, призначених для їх використання в процесі вироблення об’єднаної розвідувальної оцінки в сучасних умовах оперативного середовища, $\epsilon$ необхідною умовою успішного проведення Об'єднаних операцій 3С України, інших складових Сил оборони, в тому числі спільно з країнами-членами НАТО.

Розвідувальна оцінка. Під терміном "розвідувальна оцінка" розуміється інформаційно-аналітичний документ, який містить результати комплексного аналізу конкретної ситуації навколо противника та інших об'єктів розвідки з висновками, прогнозами та рекомендаціями в контексті забезпечення національної безпеки та національних інтересів держави.

Об'єднана розвідувальна оцінка - це опис оперативного середовища стосовно метеорологічних та океанографічних умов, оцінки противника, кіберпростору і місцевості. Це логічні висновки, отримані 3 обробленої інформації на основі знань і досвіду фахівців-аналітиків розвідки. Об'єднана розвідувальна оцінка формує усвідомлення загальної оперативної обстановки, сприяє ситуаційному розумінню командувача (командира) і плануванню операції. Така оцінка дає змогу командувачу (командиру) прийняти оптимальне рішення щодо виконання поставленого завдання.

Процес вироблення об'єднаної розвідувальної оцінки передбачає аналіз ситуації та формулювання самої оцінки, і вимагає аналітичних та логічних здібностей мислення виконавців.

Об'єднана розвідувальна оцінка включає:

a) оцінку можливостей противника і ймовірних його намірів на основі наявних розвідувальних даних;

б) ідентифікацію ймовірних планів і дій противника та ймовірність їх застосування.

Під час розроблення об’єднаної розвідувальної оцінки приймається до уваги:

а) завдання командувача (командира);

б) метеорологічні умови та характерні особливості місцевості;

в) загальний стан противника і його можливі дії на цей час;

г) характер дій противника, його слабкі сторони, можливості залучення резервів, які здатні вплинути на хід операції;

д) можлива тактика дій противника в операціях;

є) імовірні наміри противника, включаючи його цілі і завдання в найближчій і наступних операціях;

ж) соціокультурні фактори ворожого і неворожого ставлення населення в зоні проведення операціï.

Вироблення надійної розвідувальної оцінки передбачає логічну послідовність мислення, чіткий поділ фактів і припущень. Більша частина фактів і висновків об'єднаної розвідувальної оцінки будуть використані в оперативній оцінці. 
Вироблення об'сднаної розвідувальної оцінки оперативної обстановки (далі - ОРООО) - це системний, циклічний i динамічний процес, який тісно пов'язаний з окремими етапами процесу прийняття рішень командувачем (командиром). Результати процесу графічно зображуються серією схем. Ці схеми включають основні дані про місцевість, погодні умови, тактичні доктрини противника, схеми маневру противника та інші суб'єкти, що впливають на хід операції, окремі 3 яких можуть бути підготовлені заздалегідь. Безпосередньо перед і під час операції інформація постійно оновлюється 3 метою відстеження трансформації основних факторів, які можуть вплинути на діяльність сил і засобів розвідки під час конфлікту.

За розробку ОРООО відповідають органи управління розвідки. Під час цього процесу розробляються розвідувальні оцінки та інші документи в інтересах забезпечення оперативного планування та прийняття командувачем (командиром) рішень. ОРООО - це довготривалий аналітичний процес, завдяки якому командувач (командир) і підпорядковані штаби отримують перевагу у визначенні найбільш вразливих місць противника, правильно спрямовуючи в часі та просторі діяльність добувних підрозділів розвідки, а також ретельно аналізуючи вплив оперативної обстановки на хід операцій. Під час підготовки ОРООО офіцери розвідки використовують наявну інформацію, свої припущення та логічні висновки $з$ оцінки обстановки, зосереджуючи увагу на опрацюванні пріоритетів розвідувальної діяльності та оцінюванні ймовірних варіантів дій противника.

ОРООО здійснюється для формування узагальненого розуміння основних характеристик оперативної обстановки (включаючи наземний, повітряний, космічний і морський простори), а також політичних, військових економічних, соціальних, інформаційних та інфраструктурних спроможностей противника (ПВЕСІІ-аналіз), партнерів і нейтральних учасників, які можуть вплинути на хід проведення міжвидових (об'єднаних) операцій.

По мірі надходження нової інформації розвідувальна оцінка деталізується та уточнюється. ОРООО здійснюється постійно, як на початковому етапі розробки плану операції, так і в ході його виконання. Саме тому цей процес організовується в такий спосіб, щоб можна було постійно оновлювати розвідувальну оцінку. ОРООО враховує багато факторів, але основою є ПВЕСІІ-аналіз, проте у разі потреби аналізують інші чинники, наприклад, екологічний. Метою зазначеного аналізу є визначення сильних та слабких сторін противника, а також впливу різних чинників на позиції учасників операції.

ОРООО як процес та об'єднана розвідувальна оцінка, як документ, є складовими оцінки оперативної обстановки.
Порядок дій під час вироблення об'сднаної розвідувальної оцінки оперативної обстановки.

Процес вироблення ОРООО складається 3 трьох основних етапів:

1. Область оцінки. На першому етапі оцінюють вплив основних факторів на оперативну обстановку під час проведення заходів дружніми і протиборчими силами. Стосовно протидії тероризму і силам захисту, це включає в себе загрози проведенню операцій (наприклад, розмежування населення за його етнічною належністю). Оцінюють інші фактори, що впливають на оперативну обстановку: пересіченість місцевості, інфраструктуру, наявність медичних установ, погодні умови, наявність безпечних зон, інформаційну обстановку та інші;

2. Оцінка учасників. Завданням цього етапу є оцінювання дій протиборчої сторони з урахуванням обмежень, які можуть накладати погода і місцевість (як учасники конфлікту будуть вести бойові дії відповідно до своїх керівних документів або орієнтуючись на свій попередній досвід). Оцінка загрози полягає у виявленні учасника конфлікту, ідентифікації його тактичної доктрини або методів проведення операцій, визначені планом, за яким він буде досягати своєї мети;

3. Поєднання загроз. На цьому етапі результати оцінювання території порівнюють 3 планами та намірами противника відповідно до його керівних документів. Мета порівняння загроз - встановити, як зміна оперативної обстановки вплине на практичне застосування противником його доктринальних положень і їх практичну реалізацію.

Під час процесу ОРООО дотримуються такого порядку дій:

а) оцінка району (місцевості) - визначення впливу особливостей навколишнього середовища на хід операцій. Такими особливостями $є$ (але не обмежуються ними) рельєф місцевості, інфраструктура, інформаційне середовище, захищені зони, кліматичні та погодні умови, стан охорони здоров'я, кордони та лінії розмежування, релігійні та культурні особливості;

б) оцінка дій основних учасників - визначення можливих варіантів дій цих учасників незалежно від просторових або погодних обмежень, відповідно до їхніх стратегій (доктрин) та попереднього досвіду;

в) узагальнена оцінка загроз. Оцінка місцевості та оцінка дій учасників взаємопов'язані. Завдяки цьому можна визначити спроможності сил противника, нейтральних сторін та союзницьких військ, а також імовірних варіантів дій та намірів з урахуванням усієї наявної розвідувальної інформації. Зазначене дає змогу спрогнозувати подальші наслідки для військ, а також спланувати необхідні заходи розвідки та обміну розвідувальною інформацією. 
Загальні принципи ведення розвідки у процесі об'сднаної розвідувальної оцінки оперативної обстановки. У процесі ОРООО необхідно дотримуватись загальних принципів ведення розвідки, які відіграють важливу роль у процесі розвідувальної діяльності, оскільки завдяки цьому правильно вибудовується розвідувальна архітектура. Наведені принципи спрямовують роботу органів розвідки, на яких покладені завдання планування та безпосереднє ведення розвідувальної діяльності:

а) злагодженість. Процес планування розвідки забезпечує досягнення поставлених цілей і має здійснюватись в умовах повної злагодженості дій усіх розвідувальних органів (органів розвідки);

б) всебічне розуміння оперативної обстановки. Бажані результати операції повинні бути зрозумілими на всіх рівнях іiї планування та проведення. Всебічне розуміння оперативної обстановки $\epsilon$ основою та запорукою успіху;

в) консультації та спільне планування. Планування, яке проводиться у будь-якому місці, в гармонійному психологічному середовищі та на основі взаємної підтримки, є запорукою успіху комплексного підходу. Під час ведення розвідувальної діяльності, здійснення обміну та доведення інформації необхідно спонукати учасників цих процесів до всебічного співробітництва та взаємодії;

г) ефективне використання ресурсів. Успішне ведення розвідки потребує постійного балансування між вимогами (завданнями) та оптимізацією використаних зусиль і ресурсів. Такий підхід допустимий не лише для розвідки, а й для загального управління військами та планування операцій. Плануючи розвідувальну діяльність, потрібно визначити баланс між завданнями та ресурсами. Особи, які приймають рішення, мають бути обізнаними щодо ризиків, в основі яких лежить об'єктивна обмеженість ресурсів щодо ведення розвідки;

д) гнучкість та адаптивність. Планування розвідки має враховувати взаємодію з іншими підрозділами, досягнуті політичні рішення та обмеженість ресурсів. Процес планування має бути стійким, але водночас і достатньо гнучким та адаптивним для забезпечення можливості внесення раціональних змін до розроблених планів;

е) час проти глибини аналізу. Необхідно балансувати між швидким наданням оцінки та належним поглибленим аналізом. Аналітики рідко мають достатньо часу для обробки інформації, тому що розвідувально-інформаційні документи потрібно швидко відпрацьовувати. Зазначене дає змогу командувачу своєчасно вплинути на процес прийняття рішень противником. Водночас це вимагає налагодження вільного потоку інформації всередині багаторівневої архітектури органів розвідки; є) результат проти володіння. Така суперечність виникає, коли від спроможностей якогось одного органу розвідки залежить виконання певного завдання, що стоїть перед ОУВ (С). В основному завдання силам розвідки має ставити той, кому підпорядковані ці сили, на відміну від намагання задовольнити потреби максимальної кількості споживачів. У будь-якому випадку співробітники розвідки повинні сфокусуватися на надання максимально якісних розвідувальних даних. Спільні процеси мають забезпечувати проходження інформації без затримок, незважаючи на національну чи відомчу належність того чи іншого розвідувального органу (органу розвідки), а також компенсувати неповноту відомостей та недостатність сил і засобів розвідки;

ж) написання для доведення. Кожен аналітик повинен уміти розробляти розвідувально-інформаційні документи в такий спосіб, щоб вони мали якомога нижчий гриф секретності. Це вміння приходить 3 досвідом. Надання та обмін інформацією забезпечується шляхом поєднання зусиль тих, хто ставить завдання, добуває та обробляє інформацію;

3) гриф секретності визначає виконавець. Згідно $з$ прийнятими в НАТО стандартами, лише той, хто надає готовий розвідувально-інформаційний документ чи щойно добуту необроблену PI, одноосібно відповідає за визначення грифа секретності та список розсилки. І вони не можуть бути змінені без згоди автора;

и) своєчасність доведення. Немає великої користі від добутої інформації, якщо вона надійшла із запізненням, не включена до вихідного розвідувально-інформаційного документа або не відповідає розвідувальним завданням. Добуті відомості та матеріали, так само як і цілісні аналітичні документи, потрібно доводити до споживача якнайшвидше. Форми документів, які доводяться, мають відповідати стандартам НАТО або загальноприйнятим стандартам з діловодства. В окремих випадках потрібно враховувати існуючі обмеження щодо доведення інформації;

i) спільні стандарти для метаданих. Для забезпечення автоматизації обробки інформації використовують певні атрибути (теги) для маркування метаданих. Технічні параметри засобів зберігання даних, серверів та їх конфігурація мають підвищувати взаємодію між підрозділами, які добувають, узагальнюють та обробляють інформацію, і споживачами інформації;

i) стабільність проти змін. Усі процеси в розвідці виконуються ефективно за умови дотримання встановлених вимог. Водночас особливістю проведення воєнних операцій $\epsilon$ постійна зміна оперативної обстановки. Розуміння зазначеного набуватиме ще більшої ваги в майбутньому. 
Зважаючи на це, органи розвідки, діючи в умовах зростаючої невизначеності та непередбачуваності, повинні бути адаптивними та гнучкими для забезпечення процесу прийняття рішень;

й) важливість систем розвідки. Побудова розвідувальної архітектури має передбачати завчасне формування необхідних спроможностей (сил і засобів) розвідки ще до моменту виникнення конфлікту. Для цього створюються відповідні системи (мережі) 3 підключенням до них як національних розвідувальних органів країн-членів НАТО, так і органів управління розвідки в командній структурі НАТО;

к) важливість засобів розвідки. Ефективність розвідувального забезпечення залежить від комплекту сил і засобів розвідки, обладнання та інших засобів, які використовуються в розвідувальній діяльності. Їх застосування сприяє поліпшенню взаємодії та скороченню часу, який витрачається на виконання поставлених завдань;

л) моделювання.

Моделювання передбачає використання групи або декількох груп для моделювання діяльності (розігрування) учасників конфлікту з метою встановлення їх дійсних стратегічних та політичних цілей. Цей метод за допомогою ігрової команди має ефективно проілюструвати заходи та дії, які буде здійснювати противник. Моделювання допоможе вилучити упереджене ставлення до деяких чинників під час планування операції.
ОРООО споріднена з розвідувальним циклом. Під час вироблення ОРООО деякі вимоги ідентифікують і включають до розвідувального циклу. Ці вимоги надалі трансформуються в питання і відповідно до них визначаються джерела інформації та органи, на які покладатиметься добування. Ця інформація буде оброблена і використана в ОРООО, в ході планування операції та ведення бойових дій.

\section{Висновки}

Розроблення змістовних основоположних базових доктрин JP-2.0 та JP-2.1 розвідувального забезпечення ЗС України в Об'єднаних операціях відіграє важливу роль в процесі подальшого формування інших керівних документів в контексті загальної Ієрархії доктринальних документів 3С України. Важливою складовою цих доктрин має бути розділ щодо вироблення об'єднаної розвідувальної оцінки під час планування та ведення операцій в сучасних умовах у складі об'єднаного угруповання військ (сил) Збройних Сил України та інших складових сил оборони, в тому числі 3 країнами-членами НАТО. Викладені у статті концептуальні основи та підходи до вироблення об'єднаної розвідувальної оцінки 3 урахуванням керівних документів (стандартів) НАТО можуть бути корисними для фахівців розвідки, офіцерів штабів органів управління розвідки та розробників доктринальних документів з розвідувального забезпечення.

\section{Список літератури}

1. Указ Президента України “Державна програма розвитку Збройних Сил України на період до 2020 року №73/2017 від 22.07.2017”. - К., 2017. - 48 с.

2. Тимчасова інструкція з організації роботи в Міністерстві оборони України та ЗСУ щодо впровадження стандартів НАТО / затв. заст. МОУ 09.09.2016 року. - К., 2016. -10 с.

3. Наказ начальника ГШ - ГК ЗС України № 3099 від 09.12.2019 року.

4. Іващенко О.І. Концептуальні засади адаптації розвідки Збройних Сил України відповідно до стандартів НАТО / О.І. Іващенко, В.Ф. Курдюк, А.П. Огарок // Наука і техніка Повітряних Сил Збройних Сил України. - 2019. - № 2(35). C. 33-37. https://doi.org/10.30748/nitps.2019.35.04.

5. Директива з питань планування Комплексних операцій Об’єднаних ЗС HАTO V1.0: переклад з англ. мови; за заг. ред. ВДА. - К.: ВДА, 2018. - 402 с.

6. Об'єднана спільна Доктрина з питань розвідки, контррозвідки і безпеки АJP-2: переклад з англ. мови; за заг. ред. ВДА. - К.: ВДА, 2018. - 99 с.

7. Об’єднана спільна Доктрина з питань процедур розвідки АJP-2.1: переклад з англ. мови; за заг. ред. ВДА. - К.: ВДА, 2018. - $78 \mathrm{c}$

8. Станаг АЈР-2.2 - Процедури розвідки та безпеки: переклад з англ. мови; за заг. ред. ВДА. - К.: ВДА, 2018. - 126 с.

9. АСТ 75-2/Е Склад розвідки, функціональний гід навчання в області розвідки(JFATG): переклад з англ. мови; за заг. ред. ВДА. - К.: ВДА, 2018. - 102 с. $167 \mathrm{c}$.

10. АЈР-2.7 Спільна доктрина розвідувальних процедур: переклад з англ. мови; за заг. ред. ВДА. - К.: ВДА, 2018. -

\section{References}

1. The Order of the President of Ukraine (2017), "Dergavna programa rozvitku Zbroynuh Sul Ukraine na period do 2020 roky No. 73/2017 vid 22.07.2017" [State Program of Development of the Armed Forces of Ukraine for the period up to 2020 No. 73/2017 dated 22.07.2017], Kyiv, 48 p.

2. The Ministry of Defense of Ukraine (2016), "Tumhasova instrukziy z orqanizazii robotu u Ministerstvi oboronu Ukraine ta ZSU vprovadqeniy standartiv NATO" [Temporary instruction on organization of work in the Ministry of Defense of Ukraine and the Ukrainian Armed Forces on the implementation of NATO standards], Kyiv, $10 \mathrm{p}$.

3. The Order of the Chief of General Staff of the Armed Forces of Ukraine (2019), No. 3099 date 09.12.2019, Kyiv. 
4. Ivaschenko, O., Kyrdiuk, V. and Ogarok, A. (2019), "Konzeptualni zasady adaptaziy rozvidky ZSU vidpovidno do standartiv NATO" [Conceptual foundations of adaptation of the Intelligence of the Armed Forces of Ukrainian accordance with NATO standards], Science and Technology of the Air Force of Ukraine, No. 2(35), pp. 33-37. https://doi.org/10.30748/nitps.2019.35.04.

5. Military Diplomatic Academy (2018), “Durektuva z putan planuvaniy Kompleksnuh operaziy Obednanuh sul ZS NATO V1.0” [United Nations Armed Forces Integrated OperationsPlanning Directive V1.0], Kyiv, 402 p.

6. Military Diplomatic Academy (2018), "Obednana spilna Doktruna z putan rozvidku, kontrrozvidku i bezpeku AJP-2" [Joint Joint Doctrine on Intelligence, Counterintelligence and Security AJP-2], Kyiv, 99 p.

7. Military Diplomatic Academy (2018), "Spilna doktruna rozviduvalnuh proztdur AJP-2.1" [Joint doctrine of reconnaissance procedures AJP-2.1], Kyiv, 78 p.

8. Military Diplomatic Academy (2018), "Stanaq AJP-2.2 - Prozeduru rozvidku ta bezpeku" [Stanag AJP-2.2 - Intelligence and Security Procedures], Kyiv, $126 \mathrm{p}$.

9. Military Diplomatic Academy (2018), "Sklad rozvidky, funktsionalnyi hid navchannia v oblasti rozvidky (JFATG)" [Intelligence Composition, Functional Intelligence Training Guide (JFATG)], Kyiv, 102 p.

10. Military Diplomatic Academy (2018), "Spilna doktryna rozviduvalnykh protsedur" [Common Doctrine of Intelligence Procedures], Kyiv, 167 p.

Надійшла до редколегії 21.01.2020

Схвалена до друку 11.02.2020

Курдюк Володимир Федорович кандидат військових наук доцент провідний науковий співробітник військової частини А1906,

Київ, Україна

https://orcid.org/0000-0001-8696-2339

\section{Огарок Анатолій Павлович}

кандидат технічних наук професор провідний науковий співробітник військової частини А1906, Київ, Україна https://orcid.org/0000-0001-8710-4301

\section{Volodimir Kurdiuk}

Candidate of Military Sciences Associate Professor

Lead Research

of the Military Unit A1906,

Kyiv, Ukraine

https://orcid.org/0000-0001-8696-2339

\author{
Anatoly Ogarok \\ Candidate of Technical Sciences Professor \\ Lead Research \\ of the Military Unit A1906, \\ Kyiv, Ukraine \\ https://orcid.org/0000-0001-8710-4301
}

\section{ОСОБЕННОСТИ ПРОЦЕССА ВЫРАБОТКИ РАЗВЕДЫВАТЕЛЬНОЙ ОЦЕНКИ ВО ВРЕМЯ ПЛАНИРОВАНИЯ И ВЕДЕНИЯ ОПЕРАЦИЙ В СОСТАВЕ ОБЪЕДИНЕННОЙ ГРУППИРОВКИ ВОЙСК (СИЛ) ВООРУЖЕННЫХ СИЛ УКРАИНЫ}

В.Ф. Курдюк, А.П. Огарок

В статье изложены концептуальные основы и подходы к выработке разведывательной оценки во время планирования и ведения операчий в современных условиях в составе объединенной группировки войск (сил) Вооруженных Сил Украины и других составляющих сил обороны, в том числе совместно со странами-членами НАТО. Рассмотрен процеес выработки разведывательной оченки оперативной обстановки и общих принципов ведения разведки в процессе объединенной разведывательной оиенки оперативной обстановки.

Ключевые слова: доктринальный документ, объединенная группировка войск (сил), объединенная разведка, разведывательное обеспечение, объединенная разведывательная оиенка.

\section{PECULIARITIES OF THE INTELLIGENCE ASSESSMENT PROCESS DURING THE PLANNING AND CONDUCTING OPERATIONS WITHIN THE JOINT FORCES OF THE ARMED FORCES OF UKRAINE}

V. Kurdyuk, A. Ogarok

Based on the analysis of normative documents that regulate the military intelligence of the Armed Forces of Ukraine and the guidance documents (standards) of NATO member states on intelligence activities, approaches to the intelligence assessment during the planning and conducting of operations of the Armed Forces of Ukraine in the current operational environment are considered. The purpose of the article is to outline the conceptual foundations of the process of developing a joint intelligence assessment in the planning and conduct of operations in modern conditions within the Joint Armed Forces (Forces) of the Armed Forces of Ukraine, other components of the Defense Forces (including, jointly with NATO member countries ). The article notes that during operations within the Joint Forces Grouping (forces), the Armed Forces of Ukraine will have to act comprehensively in a complex operational environment where terrorism, States with hostile treatment of Ukraine and NATO Partner countries, unstable states will be possible participants and threats. states and states with crisis of state power, hybrid threats and uncontrolled proliferation of weapons. The essence and content of certain terms used in the developed doctrinal documents of the Armed Forces of Ukraine, such as intelligence assessment, joint intelligence assessment and joint intelligence assessment of operational situation, are disclosed. It describes the steps, procedure and general principles for conducting intelligence in the process of joint intelligence assessment of the operational situation. The end result is the development of meaningful basic doctrines of JP-2.0 and JP-2.1 intelligence support of the Armed Forces of Ukraine in the Joint Operations. An important component of these doctrines should be the section on the development of a joint intelligence assessment in the planning and conduct of modern-day operations in the combined forces (forces) of the Armed Forces of Ukraine and other defense forces, including with NATO member countries.

Keywords: a doctrinal document united by a group of troops. consolidated intelligence, intelligence, combined intelligence. 